\title{
Bacterial Diseases of Wheat in the Southern Ural: Manifestations, Biological Characteristics and Monitoring Features
}

\author{
A. P. GLINUSHKIN ${ }^{1 *}$, O. O. BELOSHAPKINA ${ }^{2}$, A. A. SOLOVYKH ${ }^{3}$, \\ G. V. SUDARENKOV ${ }^{3}$ and J. MOLNÁR ${ }^{1}$ \\ ${ }^{1}$ All-Russian Research Institute of Phytopathology, Federal Agency of Scientific Organization, \\ Institute str., 5, Bolshie Vyazemy, 143050 Russia \\ ${ }^{2}$ Russian State Agrarian University, Moscow Timiryazev Agricultural Academy, \\ Timiryazevskaya st. 49, Moscow, Russia \\ ${ }^{3}$ Orenburg State Agrarian University, Chelyuskintsev st. 18, Orenburg, Russia
}

(Received: 1 June 2015; accepted: 26 October 2015)

\begin{abstract}
The paper presents the results of a long-term monitoring of bacterial diseases of wheat in the steppe zone of the Southern Ural. A clear domination of the genus Xanthomonas over the genus Pseudomonas has been revealed ( 60 and $11 \%$ of the total samples collected, respectively). The frequency of a winter wheat infection with these two pathogens exceeded that of the spring wheat. The field phytosanitary assessment resulted in the observation of the earlier unknown manifestation of the Xanthomonas infection called as tip bacteriosis.

The frequency of wheat infection with Xanthomonas sp. almost did not depend on the relief type, observation period, and sowing date, though the frequency of infection observed for the northern slope and lowland clearly exceeded those observed for other relief types. The frequency of infection with Pseudomonas sp. clearly depended on the sowing date and local relief type reaching the maximum at the lowlands (19-27\%), so this relief type can be considered as a "signal" point for the early diagnostics of this pathogen.
\end{abstract}

Keywords: wheat, bacterial diseases, monitoring, Xanthomonas, Pseudomonas.

All cereals are affected by various bacterial diseases caused mainly by Pseudomonas and Xanthomonas species, which are included into the group of Proteobacteria (subgroup Gammaproteobacteria). These microorganisms represent Gram-negative rodshaped motile bacteria synthesizing various pigments and toxins. Bacteria can survive in soil, infected seeds, weeds, and plant debris. The viability of bacteria directly depends on the duration of the destruction of infected plant debris. One should note that bacteria are mainly thermophilic, and the upcoming global warming will provide them with wider ecological niches and, therefore, increase their harmfulness. An increased frequency of extreme weather conditions also facilitate the expansion of bacteria as facultative parasites over greater areas and infection of plants affected by frosts and droughts (Lazarev, 2008).

\footnotetext{
* Corresponding author; e-mail: glinale@gmail.com
} 
In Russia the most widespread and harmful bacteria are Pseudomonas syringae pv. syringae, $P$. syringae pv. atrofaciens, and $P$. marginalis, representing the infectious agents of leaf blotch, basal bacteriosis, and bacterial root rot, respectively. The first two species are usually considered together, since they have no any difference in microbiological and genetic characteristics (Ignatov et al., 2012). Bacterial diseases are often caused by two or more pathogens; for example, P. syringae pv. ramonicum Schanayder et Iluchina is one of the agents causing the brown bacteriosis of wheat. In some regions of the European Russia, the frequency of basal bacteriosis and bacterial root rot varies from 1 to $40 \%$, and the level of infection of some varieties of wheat and barley can reach 70\% (Kotlyarov, 2008).

Bacteria from the genus Xanthomonas (mainly X. translucens pv. translucens), which cause black chaff of wheat, are able to reduce yield by 10-15\% (Matveeva et al., 2006), but in the case of a hot summer, grain losses sometimes reach $90 \%$ (Ilyukhina, 1979). In the Voronezh, Lipetsk, Tambov, and North Caucasus regions, the frequency of black chaff on different varieties of spring wheat varies from 1 to $50 \%$, whereas the disease development varies from 0.1 to $40 \%$.

Grain losses, caused by bacterial diseases, makes $1-10 \%$ of the total damage caused by all plant pathogens; in the case of epiphytoties under extreme weather conditions, the resulting yield loss can reach up to $40 \%$ or even more (Glinushkin, 2009; Ignatov et al., 2012). In addition, bacterial diseases negatively influence on the quality of grain products (Kotlyarov, 2008). Finally, the potential harmfullness of bacterial toxins still remains underestimated, though they are at least as dangerous as mycotoxins (McKay and Ophel, 1993).

In the case of the steppe zone of the Southern Urals and Orenburg region, bacterial diseases of cereals, especially those of spring cereals, still have not been studied yet. At the same time, results of many studies show that the damage caused by these diseases can be significant. The purposes of this study included the determination of the species composition, geographical distribution, and biological features of phytopathogenic bacteria, revealed on wheat fields and seed material in the Southern Ural region, and the improvement of some elements of the phytosanitary monitoring for this region.

\section{Materials and Methods}

The work was carried out in 2005-2014 within the framework of a long-term survey of the phytosanitary state of seed material and agrocoenoses of spring and winter wheat of different varieties in different landscape mesoforms. The field survey and sample collection was performed in 2005-2008 (survey of different geographical points of the region) and 2011-2012 (survey of different relief forms), whereas the laboratory analysis of collected samples was completed in 2014. The data obtained for 2009-2010 were not included into consideration, since the weather conditions of these years significantly differed from the usual situation (extreme rainfalls and severe drought in 2009 and 2010, respectively).

The studied region is characterized by a dry continental climate with hot summers and cold winters. The transition periods between winter and summer are very short, precipitations in the early vegetation period are rather insufficient. The frost-free period var- 
ies from 105 to 140 days. The typical climatic features of the main agricultural districts are insufficient rainfalls, their sharp annual fluctuations, and regular droughts. According to hydrothermal coefficients (HTC), vegetation periods in 2006-2008 and 2011 were slightly dry (HTC 0.61-0.73), whereas the years 2005 and 2012 were more dry (HTC 0.44-0.49). Soil formation conditions are complex and diverse, so the soil cover is characterized by a great heterogeneity.

The field monitoring of the phytosanitary situation in agrocoenoses and collection of seed material covered the territory of ten agricultural farms representing the most typical climatic conditions of the whole steppe zone of the Southern Ural (Fig. 5).

A field sampling was carried out using a W-shaped pattern; the number of sampling points was 8-10 per a field. At each sampling point, ten plants were harvested, placed in plastic bags and transported to the laboratory for the further analysis.

The initial detection of bacterial infections of plants was performed by the visual assessment with the further manifestation of infection in a moist chamber. The percentage of infected plants was calculated by the formula

$$
p=\left(N_{\mathrm{i}} \times 100\right) / N_{\mathrm{t}}
$$

where $N_{\mathrm{i}}$ and $N_{\mathrm{t}}$ represent the number of infected plants and the total number of plants per a sample, respectively.

Fragments of plant samples with clear manifestations of bacterial infection were surface sterilized and placed on starvation agar; single bacterial colonies were obtained from the resulted bacterial mass by serial dilution method. The isolated pathogens were identified by common microscopic and microbiological methods according to Schaad (2001).

The phytosanitary evaluation of collected grain samples under laboratory conditions was performed in two steps. First, to calculate the percentage of affected seeds, collected samples were germinated in paper rolls according to the common procedure. Seven-day seedlings were visually evaluated, and grains with clear manifestations of bacterial infection were considered as infected. Second, grain samples were placed on potato agar to reveal possible bacterial infection. After a five-day incubation, the morphological assessment and microscopy of grown colonies was performed to identify pathogens as described by Shaad (2001).

The statistical treatment of obtained results was carried out using a Statistica 6.0 package.

\section{Results and Discussion}

\section{Species composition and disease manifestations}

According to the current approaches to the classification of microorganisms, due to their great variability, it is quite enough to determine them at the genus level (Vauterin et al., 1995). Results of our regional survey of wheat fields showed a clear domination of the black chaff pathogen from the genus Xanthomonas (up to $60 \%$ of the total samples collected). The frequency of pathogens causing basal bacteriosis and belonging to the genus Pseudomonas (including P. syringae pv. atrofaciens Stevans, which infects not only 
wheat, but also barley, rye, and oats), was significantly lower and reached $11 \%$ of the total samples collected. In some cases we observed a mixed infection with both bacterial genera. In addition, the affection of single winter wheat plants with brown bacteriosis, caused by a complex of bacteria, often by Pseudomonas ramonicum Schnayder et Iluchina, was observed in the form of yellow spots with brown edges located at the bottom part of stems and causing their brooming and dying.

In the case of the infection with Pseudomonas bacteria, causal agents of basal bacteriosis, we observed the appearance of leaf spots, first light and watery and then dry and brown. During the tillering stage, leaf tips remained green, while leaves themselves gradually necrotized and then died (Fig. 1). In the case of a severe disease development, coleoptiles became brown, and stem dwarfism was observed. Then glumes became brown at the bottom and black from the inner side, whereas grains became black at their germ part and red at the rest part. The formed grain often was thin and had a low germination rate.

During the first colonization of plants with Xanthomonas, we observed the wilting of shoot tips only (Fig. 2), so we called this manifestation type as "tip bacteriosis" (Glinushkin, 2009). As far as we know, such manifestation type was not described earlier by other authors. In the case of well-aired fields of spring wheat located on gentle slopes, bacterial infection was manifested only via yellow-white leaf necroses; no any bacterial exudates were observed (Fig. 3). Under more wet conditions (fields adjacent to low and flooded lands), we observed oval spots with blurred borders, which were clearly visible under sunlight and had more light colour as compared to the other part of lamina. During wet weather or heavy dewiness, these spots became dark and formed drops of exudate; later we observed a sharp discoloration of the infected leaves followed by their dying-off, especially in the presence of Pseudomonas, which increased the percentage of death plants.

Surveying the fields, we often observed small areas $(0.5-1.5 \mathrm{~m}$ or more in diameter) with withered plants died because of the severe affection of their vascular system and still live, but suppressed plants with light yellow necroses on their leaf tips (Fig. 2).

\section{Phytosanitary evaluation of collected grain samples under laboratory conditions}

The typical manifestation of bacteriosis on seeds was the following: seeds had a usual colour, but a gray-yellow mucous exudate appeared at a scutellum or, sometimes, at a groove. A mass sliming of seeds with the excretion of the endospermal part was also observed. Our study showed that later these excretions were colonized by saprotrophic fungi, mainly belonging to the genus Penicillium (70 $\pm 18 \%$; Fig. 4). These seeds often did not demonstrate any growth. A specific feature of the majority of seedlings, developed from infected seeds, was a chlorotic area at the leaf tips; many plants were also characterized by shorter stems and malformed root system. About $60-80 \%$ of such plants demonstrated the delayed growth and development under field conditions, and $\sim 50 \%$ of them demonstrated a root rot infection, started from the underground part of the stem (Glinushkin, 2009). Seeds, which had a latent infection, developed shoots with lightened leaf tips, but did not have any malformations or growth suppression. 


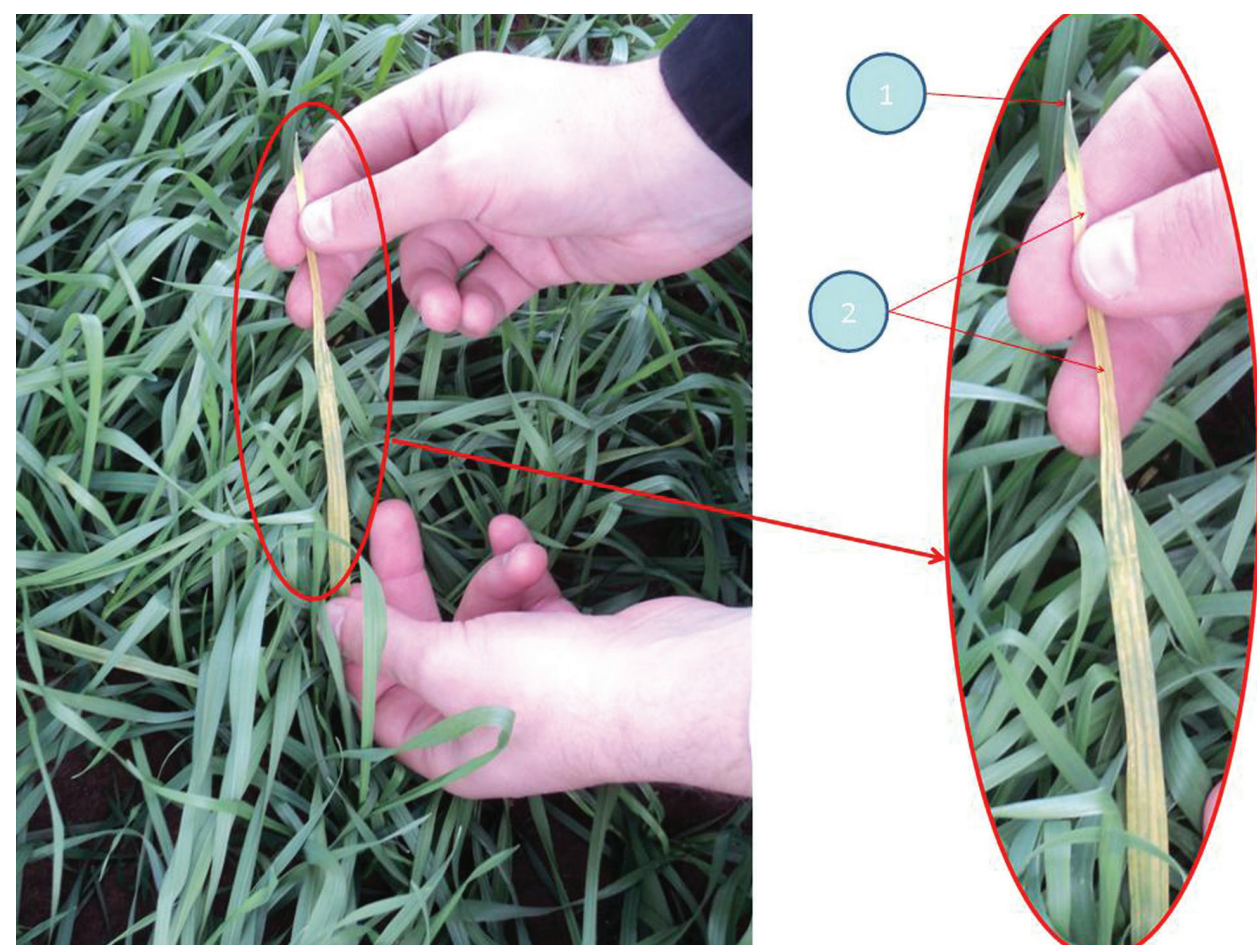

Fig. 1. Manifestation of the bacterial infection of winter wheat with Pseudomonas sp. at the tillering stage. 1 , green leaf tip; 2, necrotized leaf

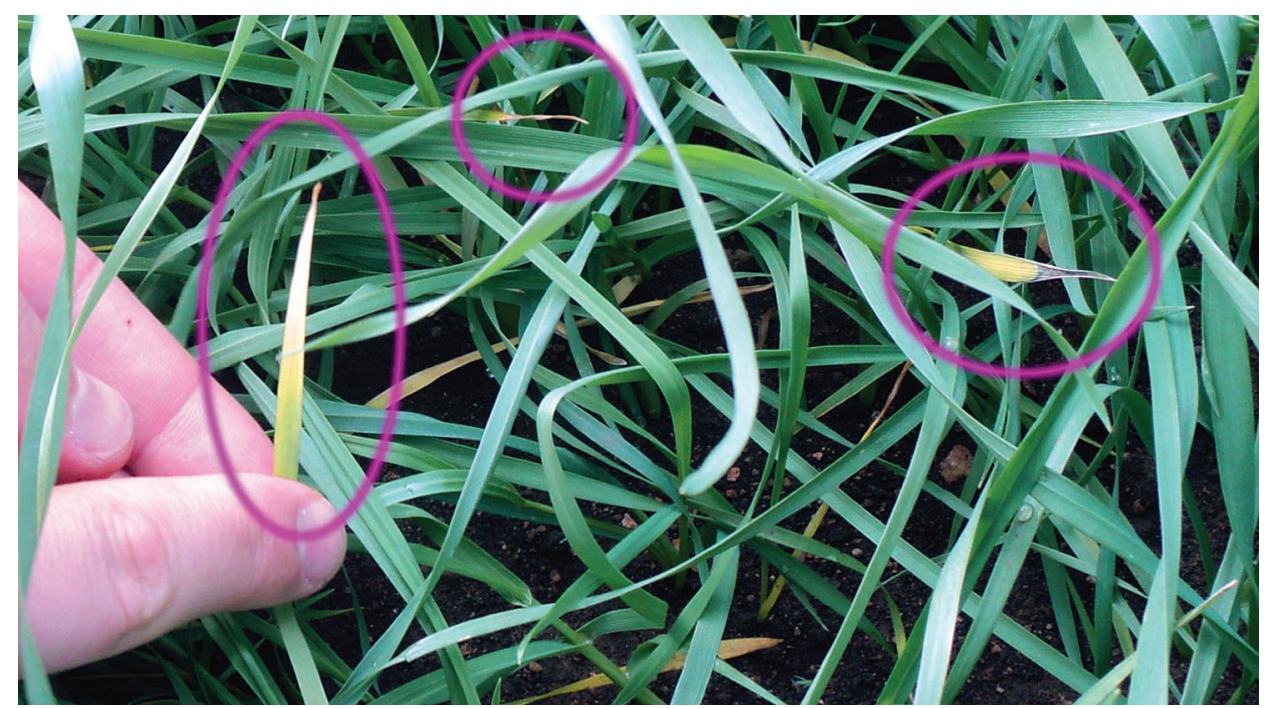

Fig. 2. Manifestation of tip bacteriosis (wilting of leaf tips only) caused by Xanthomonas sp. on winter wheat 


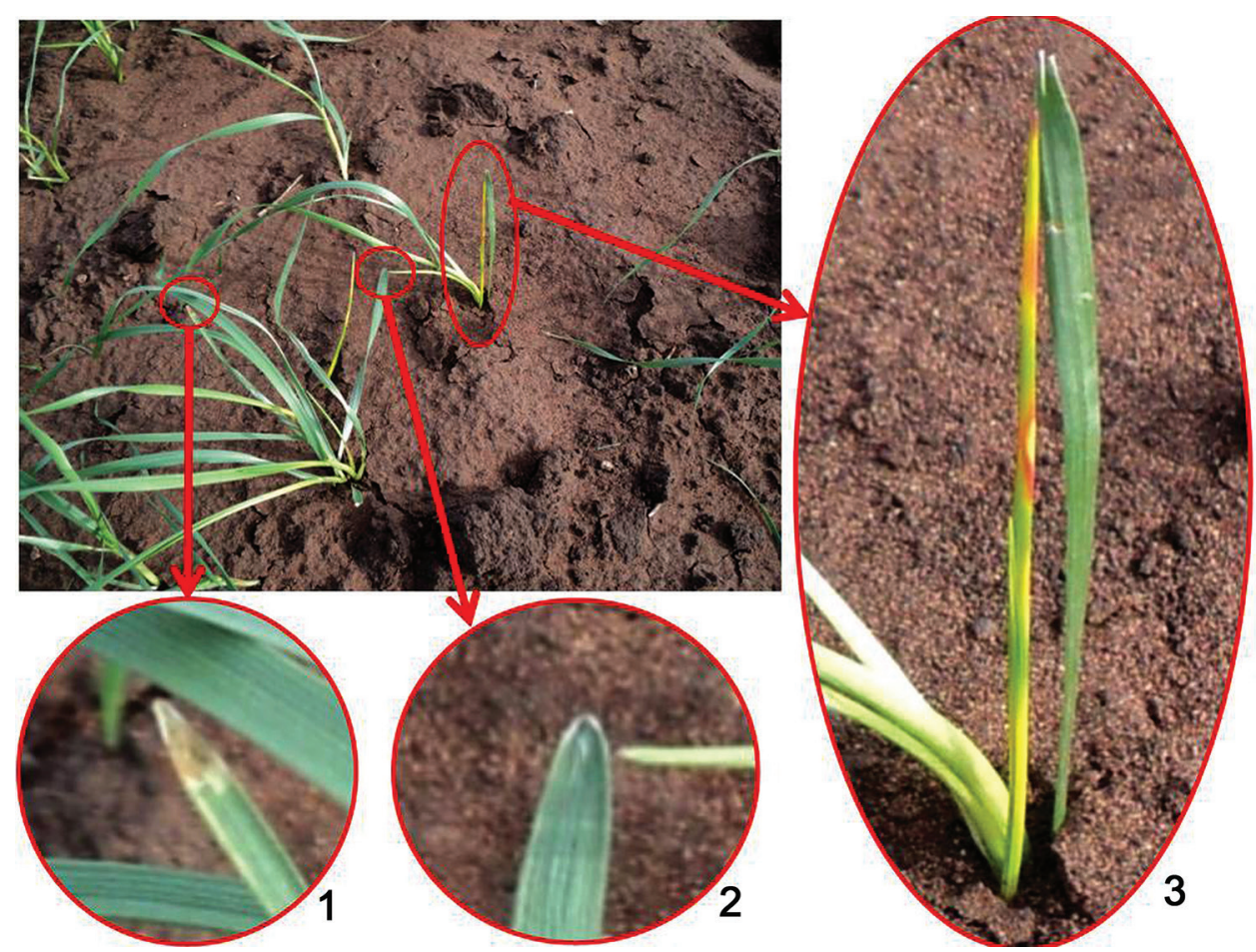

Fig. 3. Exudate-free form of the bacterial infection of wheat. 1, clear tip bacteriosis; 2, unclear tip bacteriosis; 3, yellow-white necrosis of leaves

According to the Russian State Standard, the level of seed infection should be evaluated by their germination in filter paper rolls followed by the assessment of the percentage of non-germinated seeds with clear signs of bacterial infection. During our laboratory studies (2010-2012), the use of this method allowed us to isolate Xanthomonas strains only from 0.5 to $10 \%$ of the total number of grain samples. However, the direct microbiological analysis of the same samples revealed a significantly higher percentage of infected seeds ( $60 \pm 14 \%)$; the germination rate of these seeds did not exceed $50 \%$, and only $20 \pm 10 \%$ of them were able to complete their development and form young plants. Thus, the accepted Russian standard is not able to reveal seeds with latent infection and should be supplemented with the microbiological testing.

\section{Evaluation of soil as a primary source of infection}

To confirm an assumption that soil, in which bacteria can survive on plant debris until their mineralization, can serve as a primary source of infection along with infected seeds, we arranged the following experiment. A soil sample was collected on the chernozem field, on which the frequency of bacterial infection (X.translucens) reached $100 \%$. This soil sample was mixed with sterile sand in different proportions to provide a series 


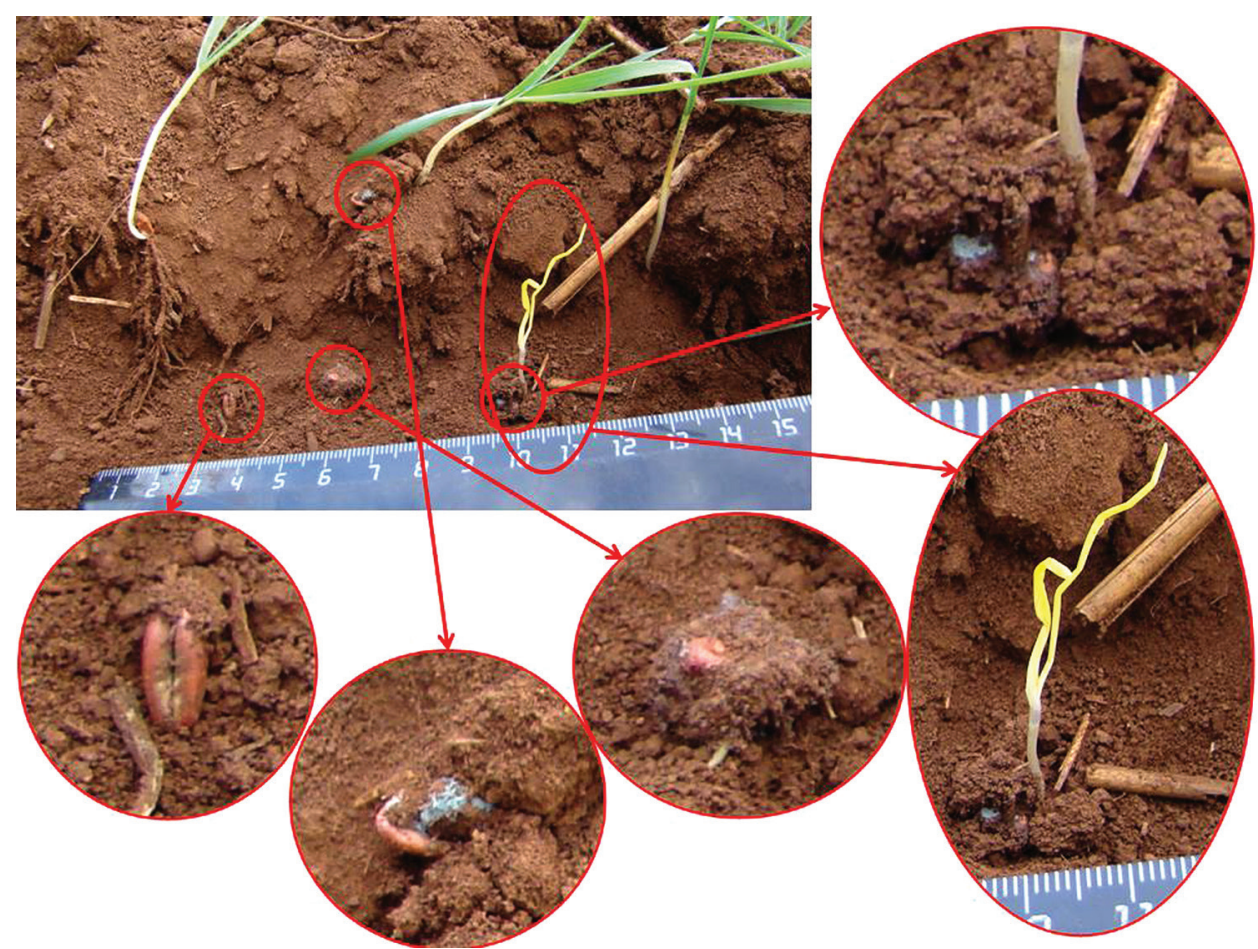

Fig. 4. Co-infection of infected winter wheat seeds with Penicillum sp. and abnormal development of plants

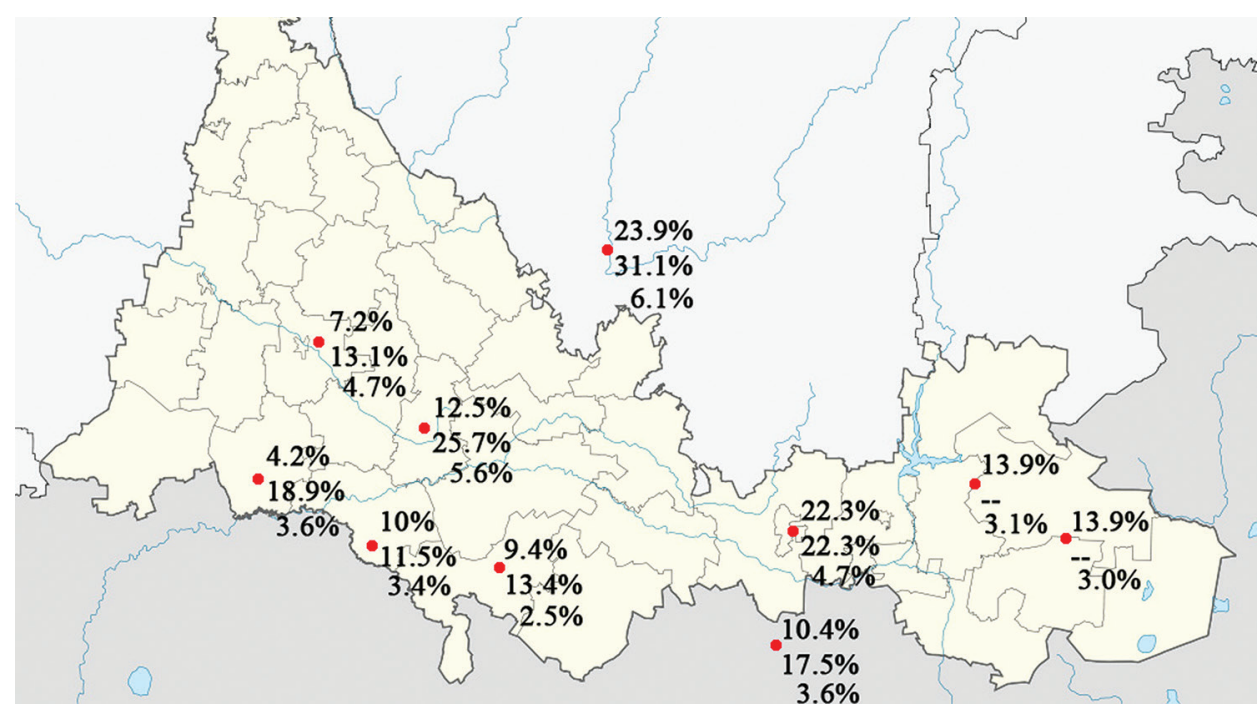

Fig. 5. Averaged frequency of bacterial infections on spring and winter wheat at different geographic points of the Orenburg region (2005-2008). Top and middle numbers indicate the data obtained for the spring and winter wheat, respectively; bottom numbers indicate the humus content in soil 
of "diluted" samples. Healthy seeds of winter wheat (Uchitel variety) were sown in these soil samples under laboratory conditions with the further assessment of their bacterial infection level. According to the earlier studies, seed infection with bacteria, persisting in soil, is possible both prior and after the seed germination; in the last case, the number of infected seedlings triples (Israilskiy, 1960). In our case, the frequency of bacterial infection of seedlings grown on pure sand was zero, as expected, whereas in the case of pure contaminated soil it was equal to $97 \pm 2 \%$. However, even in the case of the minimal soil content in the mix (1:100), we observed a high percentage of infected seedlings ( $47 \pm 2 \%)$. The similar results were obtained in the case of the use of vegetation pots. The biological crop capacity observed for plants grown on the sand substrates containing infected soil, reached 1.1-1.6 $\mathrm{t} / \mathrm{ha}$, whereas in the case of a sterile substrate it exceeded $2 \mathrm{t} / \mathrm{ha}$. Thus, the performed studies confirmed that the soil of fields highly infected with $X$. translucens can serve as a primary source of infection for sown seeds.

\section{Influence of the geographical location, humus content, and wheat type on the severity of infection}

The large-scale survey of farms located in the Orenburg region, southern part of Bashkortostan, and Northern Kazakhstan revealed a significant level of bacterial infection of wheat varying by cultures, varieties and years. Some fields of both spring and winter wheat almost did not have healthy plants. The averaged (2005-2008) frequencies of bacterial infection for different locations and wheat types are shown in Fig. 5. According to the obtained data, the frequency of infection, observed on winter wheat, exceeded that on spring wheat in all studied locations (excepting two points in the eastern part of the region, in which only spring wheat was cultivated). In the case of spring wheat, the severity of infection was minimal in the western part of the studied territory and increased in the northern and central parts. In the case of winter wheat, the maximum severity was also observed in the northern and central parts, whereas minimum values were observed for the south-west and north-west parts. It seems there is a tendency to a correlation between the severity of infection and the humus content in soil; however, to prove this hypothesis, more data are needed.

\section{Relation between the local relief, time of sowing, and disease development}

A successful phytosanitary monitoring by traditional methods is possible only for the fields located on a plain. We supposed that in the case of a multi-landscape areas with significantly varying microclimatic conditions, there should be "signal" landscape mesoforms, characterized by the strongest and earliest disease manifestations and suitable for the monitoring of the first signs of the disease appearance. To examine this assumption, we performed the monitoring of a farm located in the Perevolotsk district of the Orenburg region and characterized by the maximum number of different landscape forms (plain, lowland, southern and northern slopes). Data were collected in several different periods of 2011-2012 under conditions of the early or late sowing of the Povolzhskaya 86 variety of winter wheat. Results of the monitoring are shown in Table 1. 


\section{Table 1}

Infection of winter wheat with plant pathogenic bacteria observed on different relief forms of the Perevolotsky district of the Orenburg region

\begin{tabular}{|c|c|c|c|}
\hline \multirow[t]{2}{*}{ Time of sowing } & \multirow{2}{*}{$\begin{array}{l}\text { Date of } \\
\text { registration* }\end{array}$} & \multicolumn{2}{|c|}{ Percentage of infected plants, $\%$ of the samples collected } \\
\hline & & Xanthomonas sp. & Pseudomonas sp. \\
\hline \multicolumn{4}{|c|}{ Plain } \\
\hline & 1) 13.10 .2011 & $43.0 \pm 4.3$ & 0 \\
\hline & 2) 12.05 .2012 & $37.0 \pm 4.7$ & $13.0 \pm 2.3$ \\
\hline \multirow[t]{5}{*}{ August, 25} & 3) 12.06 .2012 & $78.0 \pm 8$ & 0 \\
\hline & 4) 25.06 .2012 & $87.0 \pm 7.3$ & 0 \\
\hline & 5) 17.07 .2012 & 0 & 0 \\
\hline & 1) 13.10 .2011 & $51.0 \pm 5$ & 0 \\
\hline & 2) 12.05 .2012 & $42.0 \pm 2.7$ & $5.0 \pm 0.8$ \\
\hline \multirow[t]{6}{*}{ September, 10} & 3) 12.06 .2012 & $75.0 \pm 4.7$ & 0 \\
\hline & 4) 25.06 .2012 & $83.0 \pm 4.7$ & 0 \\
\hline & 5) 17.07 .2012 & 0 & 0 \\
\hline & & rn slope & \\
\hline & 1) 13.10 .2011 & $56.0 \pm 4.7$ & 0 \\
\hline & 2) 12.05 .2012 & $74.0 \pm 4$ & $13.0 \pm 2.3$ \\
\hline \multirow[t]{5}{*}{ August, 25} & 3) 12.06 .2012 & $83.0 \pm 4$ & 0 \\
\hline & 4) 25.06 .2012 & $97.0 \pm 6.3$ & 0 \\
\hline & 5) 17.07 .2012 & 0 & 0 \\
\hline & 1) 13.10 .2011 & $42.0 \pm 3$ & 0 \\
\hline & 2) 12.05 .2012 & $57.0 \pm 3.7$ & $2.0 \pm 0.7$ \\
\hline \multirow[t]{6}{*}{ September, 10} & 3) 12.06 .2012 & $75.0 \pm 5.7$ & 0 \\
\hline & 4) 25.06 .2012 & $91.0 \pm 5$ & 0 \\
\hline & 5) 17.07 .2012 & 0 & 0 \\
\hline & & vland & \\
\hline & 1) 13.10 .2011 & $58.0 \pm 5$ & $2.0 \pm 1.2$ \\
\hline & 2) 12.05 .2012 & $67.0 \pm 4$ & $19.0 \pm 2.2$ \\
\hline \multirow[t]{5}{*}{ August, 25} & 3) 12.06 .2012 & $83.0 \pm 4.3$ & $23.0 \pm 2.7$ \\
\hline & 4) 25.06 .2012 & $92.0 \pm 4$ & $27.0 \pm 3.7$ \\
\hline & 5) 17.07 .2012 & 0 & 0 \\
\hline & 1) 13.10 .2011 & $43.0 \pm 3$ & 0 \\
\hline & 2) 12.05 .2012 & $63.0 \pm 5.2$ & $5.0 \pm 1.2$ \\
\hline \multirow[t]{6}{*}{ September, 10} & 3) 12.06 .2012 & $86.0 \pm 6$ & $14.0 \pm 1.7$ \\
\hline & 4) 25.06 .2012 & $94.0 \pm 4.7$ & 0 \\
\hline & 5) 17.07 .2012 & 0 & 0 \\
\hline & & rn slope & \\
\hline & 1) 13.10 .2011 & $67.0 \pm 5.3$ & $1.0 \pm 0.8$ \\
\hline & 2) 12.05 .2012 & $54.0 \pm 5$ & $14.0 \pm 2$ \\
\hline \multirow[t]{5}{*}{ August, 25} & 3) 12.06 .2012 & $88.0 \pm 7.3$ & $21.0 \pm 2.7$ \\
\hline & 4) 25.06 .2012 & $93.0 \pm 5$ & $23.0 \pm 2.3$ \\
\hline & 5) 17.07 .2012 & 0 & 0 \\
\hline & 1) 13.10 .2011 & $45.0 \pm 4.3$ & 0 \\
\hline & 2) 12.05 .2012 & $72.0 \pm 3.7$ & $3.0 \pm 1$ \\
\hline \multirow[t]{3}{*}{ September, 10} & 3) 12.06 .2012 & $90.0 \pm 4.7$ & $11.0 \pm 3$ \\
\hline & 4) 25.06 .2012 & $97.0 \pm 3.3$ & $13.0 \pm 2.7$ \\
\hline & 5) 17.07 .2012 & 0 & 0 \\
\hline
\end{tabular}

* Observations were made in the following periods: 1) pre-winter period; 2) beginning of vegetation period; 3 ) booting stage; 4) milky ripeness stage; 5) complete ripeness stage. 
According to the obtained data, the frequency of wheat infection with Pseudomonas sp. clearly depended on the sowing date and relief type. The level of infection was clearly lower in the case of the late sowing (2-5\% vs. 13-19\% (beginning of vegetation period), and $13-14 \%$ vs. $23-27 \%$ (complete ripeness stage) for the late and early sowing, respectively). In the case of the plain and southern slope, these pathogens were observed only in the beginning of the vegetation period (13 and 5\% for the early and late sowing, respectively), whereas in the case of the lowland and northern slope, they were also revealed at the later stages. The maximum level of infection was observed for the lowland (19-27\% through the vegetation season) that makes it possible to propose this relief type as a "signal" mesoform for the early diagnostics of this pathogen.

The level of infection with Xanthomonas sp. almost did not depend on the relief type; these pathogens were observed within the whole observation period. The obtained data did not show any clear correlation between the level of infection and sowing date. At the same time, at the beginning of the vegetation period (see table data for 12.05.2012), the percentage of infected plants varied between different relief types. For example, in the case of the late sowing, the value of this parameter for the northern slope and lowland clearly exceeded those registered for other relief types. In the case of the early sowing, no any clear dependence of this kind was revealed. Nevertheless, the revealed tendency requires the further investigation, since it will probably also provide any "signal" relief forms for the monitoring of Xanthomonas infection.

\section{Conclusion}

Results of our regional survey of wheat fields showed a clear domination of the black chaff pathogen from the genus Xanthomonas over the genus Pseudomonas (60 and $11 \%$ of the total samples collected, respectively).

The performed phytosanitary assessment of wheat fields resulted in the observation of the earlier unknown manifestation of the Xanthomonas infection called as tip bacteriosis. The comparison of the State Standard for the phytosanitary assessment of a seed material with the common microbiological testing showed that the standard approach is rather insufficient in the case of a latent infection and should be revised.

The ability of $X$. translucens to survive in soil and work as the primary source of infection for the sown seeds was experimentally confirmed for the fields with significantly infected plants.

The analysis of samples collected in different geographical locations showed that the frequency of bacterial infection, observed on winter wheat, exceeded that on spring wheat. For both wheat types, the severity of infection was the highest in the northern and central parts of the studied region, whereas in the western locations it was minimal. The obtained data correlate with the humus content in the soil $(r=0.7)$.

The frequency of wheat infection with Pseudomonas sp. clearly depended on the sowing date, being lower in the case of the late sowing, and on the local relief type. The maximum values of the assessed parameter were observed in the lowlands (19-27\%) that 
makes it possible to propose this relief type as a "signal" point for the early diagnostics of this pathogen.

The frequency of infection with Xanthomonas sp. almost did not depend on the relief type and the observation period. The obtained data did not show any clear correlation with the sowing date. At the same time, in the case of a late sowing, the frequency of infection observed for the northern slope and lowland clearly exceeded those observed for other relief types. The revealed tendency requires the further investigation, since it will probably also provide any "signal" relief forms for the monitoring of Xanthomonas infection.

\section{Acknowledgement}

The study was financially supported by the Russian Foundation for Basic Research (project no. 15-2905893).

\section{Literature}

Glinushkin, A. P. (2009): Wheat and bread: agroecological and technological protection efficiency of spring wheat in the steppe zone of the Southern Urals. Saratov, 198 p. (in Russian).

Ignatov, A. N., Knyazev, A. N. and Vinogradova, S. V. (2012): Bacterial diseases in Russia: the threat is real. Zashchita rastenii (Plant Protection) 6, 16-17. (in Russian).

Ilyukhina, M. K. (1979): Bacterial diseases of spring wheat. Selskohozyaistvennaya biologiya 8, 50-51 (in Russian).

Israilskiy, V. P. (1960): Bacterial diseases of plants. Moscow, 468 p. (in Russian).

Kotlyarov, V. V. (2008): Bacterial diseases of cultivated plants. Kuban State Agrarian University Press, Krasnodar, 325 p. (in Russian).

Lazarev, A. M. (2008): Bacterial diseases of wheat. Grain farming 1-2, pp. 61-65. (in Russian).

Matveeva, E. V., Polityko, V. A. and Ignatov, A. N. (2006): Black rot of cereals: phenotypic and molecular characteristics of the Russian strains of Xanthomonas translucens. Agro XXI. No. 10-12. pp. 27-30. (in Russian).

McKay, A. C. and Ophel, K. M. (1993): Toxigenic Clavibacter/Anguina associations infecting grass seedheads. Annu. Rev. Phytopathol. 31, 151-167.

Schaad N. W. (2001): Initial identification of common genera. In: N. W. Schaad, J. B. Jones and W. Chun (eds): Laboratory Guide for Identification of Plant Pathogen Bacteria. Third edition. American Phytopathological Society Press, St Paul, USA, pp. 14-27.

Vauterin, L., Hoste, B., Kersters, K. and Swings, J. (1995): Reclassification of Xanthomonas. Int. J. Syst. Bacteriol. 45, 472-489. 
